\title{
PERAN PUSAT PELAYANAN TERPADU PEMBERDAYAAN PEREMPUAN DAN ANAK (P2TP2A) DI INDONESIA DALAM MENANGANI KASUS HUMAN TRAFFICKING
}

\author{
Andi Fardian ${ }^{1}$, Gerralda Chintyaarizma Putriaksa ${ }^{2}$ \\ Universitas Gadjah Mada \\ Bulaksumur, Caturtunggal, Kec. Depok, Kabupaten Sleman, Yogyakarta 55281 \\ Andifardian246@gmail.com
}

\begin{abstract}
Abstrak
Human trafficking atau perdagangan orang telah menjadi masalah serius di Indonesia. Salah satu upaya yang dilakukan pemerintah untuk meminimalisir sekaligus menangani kasus tindak pidana perdagangan orang adalah membentuk Pusat Pelayanan Terpadu Perlindungan Perempuan dan Anak (P2TP2A). Penelitian ini bertujuan untuk mengetahui peran P2TP2A di Indonesia menangani kasus buman trafficking. Penelitian ini berjenis kualitatif deskriptif. Pengumpulan data menggunakan teknik wawancara, observasi, dan dokumentasi. P2TP2A di Indonesia, dalam kaitannya dengan penanganan tindak pidana perdagangan orang (TPPO), telah melakukan beberapa hal, antara lain:pencegahan, menerima pengaduan, penyelidikan, rehabilitasi, penanganan, reintegrasi (pemulangan), pelatihan kemandirian. Masalah dan kendala yang dihadapi oleh P2TP2A, antara lain sebagai berikut:: pendanaan, masyarakat enggan untuk melapor adanya masalah, proses penyesuaian kelembagaan yang baru, tidak semua instansi pemerintah yang menangani TPPO memahami prosedur, belum jelasnya kebijakan restitusi, belum adanya SOP pelayanan korban sehingga pelayanannya berjalan sendirisendiri, adanya tumpang-tindih tupoksi antar-stakeholder, dan tidak semua orang bekerja dengan empati.
\end{abstract}

Kata Kunci: Perdagangan Orang, Peran, P2TP2A

\begin{abstract}
Human trafficking has become a serious problem in Indonesia. One of the efforts made by the government to minimize and handle the buman trafficking is to establish an Integrated Service Center for the Protection of Women and Children. This study aims to determine the role of Integrated Service Center for the Protection of Women and Childrenin Indonesia in handling buman trafficking cases. This research is a descriptive qualitative. Data collection uses interview, observation, and documentation techniques. Integrated Service Center for the Protection of Women and Childrenin Indonesia, in relation to the handling of human trafficking has done several things, including: prevention, receiving complaints, investigations, rehabilitation, handling, reintegration (return), independence training. Problems and obstacles faced byIntegrated Service Center for the Protection of Women and Childreninclude the following: funding, people are reluctant to report problems, a new institutional adjustment process, not all government agencies that handle human trafficking cases understand procedures, unclear restitution policies, lack of SOP for victim services so the service runs independently, there is overlap between the stakeholders, and not everyone works with empathy.
\end{abstract}

Keywords: Human Trafficking Role, Integrated Service Center for the Protection of Women and Children

\section{A. Pendahuluan}

Dewasa ini buman trafficking adalah satu satu permasalahan serius yang dihadapi oleh warga dunia dan juga Indonesia. Ada banyak kasus buman trafficking yang sedang ditangani di Indonesia. Pelaku menggunakan berbagai modus. Human

\footnotetext{
${ }^{1}$ Mahasiswa Master Pembangunan Sosial dan Kesejahteraan Universitas Gadjah Mada

${ }^{2}$ Mahasiswa Master Ilmu Hukum Universitas Airlangga
} 
trafficking atau perdagangan manusia merupakan salah satu masalah kontemporer yang tengah mendapatkan perhatian serius. Karakteristiknya bersifat represif dengan tujuan eksploitasi manusia (individu atau kelompok). Luasnya pengaruh dan dampak ancaman yang ditimbulkan membuat isu buman trafficking diklasifikasikan sebagai bentuk kejahatan luar biasa (extra ordinary crime). ${ }^{3}$

Di sisi lain, perdagangan manusia (buman trafficking) juga didefinisikan sebagai semua tindakan yang melibatkan pemindahan, penyelundupan atau menjual manusia baik di dalam negeri maupun antarnegara melaui mekanisme paksaan, ancaman, penculikan, penipuan dan memperdaya atau menempatkan seseorang dalam situasi sebagai tenaga kerja paksa seperti prostitusi paksa, perbudakan dalam kerja domestik, belitan utang atau praktik-praktik perbudakan lainnya. Di lain pihak, United Nations Office on Drugs and Crime (UNODC), salah satu badan yang berada di bawah naungan Perserikatan Bangsa-Bangsa (PBB) yang memiliki konsentrasi terhadap permasalahan mengenai perdagangan manusia dan penyelundupan imigran gelap, mendefinisikan perdagangan manusia sebagai tindak kejahatan terhadap manusia dengan cara merekrut, mengangkut, memindahkan, menyembunyikan atau menerima seseorang melalui kekerasan, paksaan dan tindakan jahat lainnya dengan tujuan untuk mengeksploitasi mereka. Penyelundupan imigran adalah tindak kejahatan untuk mendapatkan uang atau keuntungan materi lainnya dengan cara memasukkan orang ke dalam suatu negara dimana orang tersebut bukan merupakan warganegara negara tersebut. ${ }^{4}$

Di Indonesia, kasus perdagangan manusia telah menjadi topik pembicaraan yang mengemuka baik dalam forum nasional maupun internasional. Kasus buman trafficking di Indonesia kian banyak. Hal tersebut setidaknya terlihat dari jumlah kasus tindak pidana perdagangan orang di Indonesia sejak tahun 2011-2015 yang dihimpun dari Biro Pengendalian operasi, Markas Besar Kepolisian Negara Republik Indonesia. Pada tahun 2011, jumlah tindak pidana perdagangan manusia berjumlah 347.605 orang dan meningkat pada tahun 2015 berjumlah 352.936 orang. Meskipun pada tahun 2012 hingga tahun 2014 jumlah tindak pidana perdagangan manusia mengalami penurunan dari 341.159 orang menjadi 325.317

\footnotetext{
${ }^{3}$ Everd Scor Rider Daniel, dkk., “ Human Trafficking di Nusa Tenggara Timur”, Social Work Jurnal Vol.7 No.1 Halaman 1-129

${ }^{4}$ United Nations Office on Drug and Crime (UNODC), 2012, World Drug Report. United Nations publication, Sales No. E.12.XI.1
} 
orang. Namun, terlihat bahwa pada tahun 2015 mengalami jumlah tindak pidana perdagangan manusia kenaikannya sangat signifikan. Hal yang mengkhawatirkan bahwa kasus-kasus tindak pidana kejahatan perdagangan manusia di Indonesia semakin marak terjadi.

Pada kontek pencatatan kasus buman trafficking, Mahkamah Agung menerapkan mekanisme pencatatan yang komprehensif untuk data pengadilan secara nasional. Mahkamah Agung melaporkan terjadinya 316 tuntutan dan 279 putusan pada 2018, menurun bila dibandingkan dengan 407 tuntutan dan 331 hukuman pada $2017 .^{5}$

Dengan mempertimbangkan kasus buman trafficking yang kian besar itu, pemerintah membentuk P2TP2A (Pusat Pelayanan Terpadu Perlindungan Perempuan dan Anak) pada tahun 2009. Pembentukan P2TP2A juga didasari bahwa korban perdagangan orang adalah dari kalangan anak dan perempuan.

Dasar hukum pembentukan P2TP2A adalah Peraturan Pemerintah Nomor 9 Tahun 2008 tentang Tata Cara dan Mekanisme Pelayanan Terpadu bagi Saksi dan atau Korban Tindak Pidana Perdagang Orang. Sejumlah provinsi dan kabupaten/kota di Indonesia telah membentuk P2TP2A yang salah satu tujuannya adalah untuk memberikan pelayanan terhadap perempuan dan anak yang menjadi korban tindak kekerasan termasuk tindak pidana perdagangan orang serta melakukan upaya preventif atau pencegahan terhadap terjadinya kejahatan perdagangan orang (buman trafficking).

Dari latarbelakang di atas, maka permasalahan yang muncul adalah bagaimana peran P2TP2A dalam pemberantasan tindak pidana orang dan adakah kendala dalam penanganan pemberantasan orang oleh P2TP2A di Daerah Istimewa Yogyakarta.

\section{B. Telaah Konsep}

\section{Perdagangan Orang}

Human Trafficking atau perdagangan orang dalam tulisan ini dipakai untuk mengistilahkan tindakan perdagangan manusia. Terminologi istilah trafficking merupakan isu baru di Indonesia. Sampai saat ini belum ada terjemahan yang

${ }^{5}$ Kedutaan Besar dan Konsulat AS di Indonesia, 2019, Laporan Tahunan Perdagangan Orang 2019. 
tepat dalam bahasa Indonesia dan dapat dengan jelas membedakan dari "trading" (perdagangan). Meskipun dengan penggunaan persamaan kata yang kurang tepat, istilah perdagangan digunakan untuk menerjemahkan istilah trafficking. ${ }^{6}$

Human Trafficking dalam pengertian sederhana merupakan sebuah bentuk perdagangan modern yang mana tidak hanya merampas hak asasi manusia sebagai korban, tetapi juga membuat mereka rentan terhadap penganiayaan atau siksaan fisik, dan kerja paksa. Hal tersebut dapat menyebabkan trauma psikis, bahkan cacat atau kematian.

Pasal 1 Angka 1 Undang Nomor 21 Tahun 2007 tentang Pemberantasan Tindak Pidana Perdagangan Orang menyebutkan definisi perdagangan orang sebagai:

"Tindakan perekrutan, pengangkutan, penampungan, pengiriman, pemindahan, atau penerimaan seseorang dengan ancaman kekerasan, penggunaan kekerasan, penculikan, penyekapan, pemalsuan, penipuan, penyalahgunaan kekuasaan atau posisi rentan, penjeratan utang atau memberi bayaran atau manfaat, sehingga memperoleh persetujuan dari orang yang memegang kendali atas orang lain tersebut, baik yang dilakukan di dalam negara maupun antar negara, untuk tujuan eksploitasi atau mengakibatkan orang tereksploitasi”.

\section{Bentuk-bentuk Perdagangan Orang}

Bentuk- bentuk perdagangan orang di Indonesia, antara lain: ${ }^{8}$

a. Dijadikan sebagai pekerja rumah tangga;

b. Dipekerjakan di klub-klub malam atau tempat-tempat lain yang serupa (diantaranya sebagai pemandu karaoke);

c. Dijadikan sebagai pelacur;

d. Dipekerjakan sebagai model, artis atau penyanyi pada industri pornografi;

e. Dipekerjakan secara paksa sebagai penjual obat-obatan terlarang;

f. Bekerja di luar negeri;

g. Kawin kontrak;

h. Eksploitasi anak untuk dijadikan sebagai pengemis;

\footnotetext{
${ }^{6}$ Supardjaja, Komariah, E.,2002, Ajaran Sifat Melawan Hukum Materil dalam Hukum Pidana, Studi Kasus tentang Penerapan dan Perkembangannya dalam Yurisprudensi, Bandung: Alumni

7 Ibrahim, Imam, A, 2013, Tinjauan Viktimologis Terhadap Kejatahan Perdagangan Orang (Human Trafficking) Di Kota Bandung. Makassar: Universitas Hasanuddin

${ }^{8}$ Hakrisnowo, Hakristuti, 2003, Indonesia Court Report: Human Trafficking, Jakarta: UI
} 
i. Perdagangan bayi yang meliputi penculikan bayi, penculikan wanita hamil, peminjaman uang kepada orang tua bayi yang tidak mungkin bisa dikembalikan, sehingga konsekuensinya mereka harus mengganti dengan bayi mereka;

j. Praktik penyamaran sebagai dokter di rumah sakit;

k. Penipuan dengan kedok penawaran kerja yang tidak berat dengan imingiming gaji yang tinggi;

1. Penipuan dengan kedok penawaran kerja pada perempuan yang ternyata dipaksa untuk menjadi pelacur;

m. Penculikan bayi atau ibu hamil yang memiliki kerterbatasan ekonomi untuk bersalin, caranya dengan menawarkan bantuan biaya persalinan. Pada saat melahirkan, bayi ibu itu diambil paksa oleh pelaku untuk diperdagangkan;

n. Anak dipaksa bekerja selayaknya orang dewasa dengan waktu yang melebihi batas kemampuan, tanpa diperhatikan keselamatan dan kesehatannya serta tidak mendapatkan gaji.

\section{Lembaga P2TP2A}

Pusat Pelayanan Terpadu Pember-dayaan Perempuan dan Anak (P2TP2A) merupakan pusat layanan terpadu yang dibentuk oleh pemerintah berbasis masyarakat, yang diharapkan sebagai pusat pelayanan yang terintegrasi. Pusat pelayanan yang terintegrasi itu meliputi: pusat rujukan, pusat konsultasi usaha, konsultasi kesehatan reproduksi, konsultasi hukum, pusat pela-yanan krisis terpadu, pusat pelayanan terpadu, pusat pemulihan trauma (trauma center), pusat penanganan krisis perempuan (women crisis center), pusat pelatihan, pusat informasi iptek, rumah aman (shelter), rumah singgah atau bentuk lainnya. ${ }^{9}$

P2TP2A memiliki fungsi sebagai pertama, pusat informasi; kedua, pusat pelayanan; dan ketiga sebagai pusat pemberdayaan. Sebagai pusat informasi diharapkan P2TP2A mampu memberikan informasi kepada perempuan dan anak tentang segala aspek diantaranya informasi pendidikan,

${ }^{9}$ Utami, P. N, 2016, Optimalisasi Pemenuban Hak Korban Kekerasan terbadap Perempuan melaluni Pusat terpadu, Jurnal HAM 7(1), 55-67 
kesehatan, ekonomi, hukum, politik, kekerasan terhadap perempuan dan anak, pelatihan atau kursus-kursus dan lain sebagainya. ${ }^{10}$

P2TP2A adalah pusat pelayanan yang terintegrasi dalam upaya pemberdayaan perempuan di berbagai bidang pembangunan, serta perlindungan perempuan dan anak dari berbagai jenis diskriminasi dan tindak kekerasan, yang dibentuk oleh pemerintah berbasis masyarakat. Sedangkan pelayanan terpadu adalah serangkaian kegiatan untuk melakukan perlindungan bagi korban kekerasan, termasuk tindak pidana perdagangan orang yang dilaksanakan secara bersama-sama oleh instansi atau lembaga terkait sebagai satu kesatuan penyelenggaraan rehabilitasi kesehatan, rehabilitasi sosial, pemulangan, reintegrasi sosial dan bantuan hukum (Permen Pemberdayaan Perempuan dan Perlindungan Anak Nomor 6 tahun 2015 tentang Sistem Pemberdayaan Perempuan dan Perlindungan Anak).

\section{Metode Penelitian}

Penelitian ini berjenis kualitatif dengan pendekatan deskriptif. Metode penelitian kualitatif adalah metode penelitian yang berlandaskan pada filsafat postpositivisme, digunakan untuk meneliti pada kondisi objek yang alamiah, dimana peneliti adalah instrumen kunci, pengambilan sampel sumber data dilakukan secara purposive dan snowball, teknik pengumpulan data secara trianggulasi (gabungan), analisis data bersifat induktif/kualitatif, dan hasil penelitian kualitatif lebih menekankan makna daripada generalisasi. ${ }^{11}$

Teknik pengambilan data menggunakan teknik wawancara, observasi, dan dokumentasi. Informan penelitian ini P2TP2A di wilayah pulau jawa dengan pertimbangan biaya dan waktu penelitian, antara lain PPT (Pusat Pelayanan Terpadu) Jawa Timur, P2TP2A Jawa Tengah, P2TP2A Jawa Barat, dan P2TP2A Daerah Istimewa Yogyakarta.

Teknik analisa mengikuti pendekatan analisis deskriptif kualitatif dengan menggunakan model Miles and Huberman yang meliputi: 1) Data reduction (reduksi data), yakni merangkum, memilih hal-hal pokok dan memfokuskan pada hal-hal

\footnotetext{
${ }^{10}$ Rafikah, R., 2017. Peranan pusat pelayanan terpadu pemberdayaan perempuan dan anak (P2TP2A) dalam menghapuskan kekerasan dalam rumah tangga (KDRT) di kota Bukittinggi. Islam Realitas: Journal of Islamic \& Social Studies, 1(2), 173- 186. Alfabeta

${ }^{11}$ Sugiyono, 2010, Metode Penelitian Pendidikan, Pendekatan Kualitatif, dan R\&D, Bandung:
} 
penting dari sejumlah data lapangan telah diperoleh dan mencari polanya. 2) Data display (Penyajian data), yakni menampilkan data yang telah direduksi yang sifatnya sudah terorganisir dan mudah dipahami. Data dalam penelitian ini disajikan dalam bentuk deskripsi kata-kata dari kutipan wawancara dan gambar dengan maksud menjaga keorisinalitas data. 3) Conclution drawing/verification (kesimpulan), yakni akumulasi dari kesimpulan awal yang disertai dengan buktibukti valid dan konsisten (kredibel), sehingga kesimpulan dihasilkan dalam penelitian ini diarahkan untuk menjawab seluruh rumusan permasalahan.

\section{Pembahasan}

\section{Peran P2TP2A dan Masalah-Masalah yang Dihadapi dalam Pemberantasan Tindak Perdagangan Orang}

P2TP2A adalah kependekkan dari Pusat Pelayanan Terpadu Pemberdayaan Perempuan dan Perlindungan Anak. Posisi P2TP2A berada di bawah koordinasi Dinas Pemberdayaan Perempuan dan Perlindungan Anak, dimana di setiap daerah berbeda nomenklaturnya karena didasarkan kebutuhan tiap-tiap daerah. Dinas Pemberdayaan Perempuan dan Perlindungan Anak di setiap daerah adalah kepanjangan tangan dari Kementerian Pemberdayaan Perempuan dan Perlindungan Anak Republik Indonesia. Namun, karena adanya kebijakan desentralisasi atau otonomi daerah, maka segala kebijakan diserahkan kepada pemerintah daerah. Pada dasarnya, dasar pembentukan P2TP2A adalah Kitab Undang-Undang Hukum Pidana, Undang-Undang Perlindungan Anak Nomor 23 Tahun 2002 (yang sekarang telah diperbaharui menjadi Undang-Undang Nomor 35 Tahun 2014; dan Undang-Undang Nomor 21 Tahun 2007 tentang Pemberantasan Tindak Pidana Perdangan Orang (Human Trafficking). Meskipun demikian, pembentukan P2TP2A, pada kenyataannya tidak serentak, baik di tingkat provinsi maupun di tingkat kabupaten/kota.

Di Provinsi Jawa Timur, ada yang namanya Pusat Pelayanan Terpadu (PPT). PPT Jawa Timur terbentuk sejak tahun 2004 (3 tahun sebelum UndangUndang Nomor 21 Tahun 2007 tentang Pemberantasan Tindak Pidana Perdagangan Orang, disahkan). Pembentukan PPT Jawa Timur disebabkan diperlukannya lembaga khusus untuk melakukan pencegahan dan penanganan 
kasus tindak pidana perdagangan orang dan tindak kekerasan terhadap perempuan dan anak. Landasan hukumnya adalah SK Gubernur Jawa Timur No.188/128/kpts/013/2017 Tentang Tim Pengelola PPT RS. Bhayangkara Korban Trafficking dan KDRT. Untuk diketahui bahwa SK tersebut diganti setiap tahunnya. PPT Jawa Timur adalah satu-satunya PPT yang berbasis rumah sakit di Indonesia.

Di Provinsi Daerah Istimewah Yogyakarta, P2TP2A “ Rekso Diyah Utami” dibentuk pada tahun 2005, dengan keputusan Gubernur Daerah Istimewah Yogyakarta No.132/KEP/2005.

Pada tahun 2017, melalui Peraturan Gubernur Jawa Tengah Nomor 95 Tahun 2016 tentang Organisasi Dan Tata Kerja Unit Pelaksana Teknis Dinas Pemberdayaan Perempuan, Perlindungan Anak, Pengendalian Penduduk dan Keluarga Berencana Provinsi Jawa Tengah, PPT di Provinsi Jawa Tengah kelembagaannya berubah menjadi UPTD Kelas B yang disebut dengan Satuan Pelayanan Terpadu untuk koordinasi penanganan tindak pidana perdagangan orang di Provinsi Jawa Tengah dibentuk Gugus Tugas Pencegahan dan Penanganan Tindak Pidana Perdagangan Orang dengan Surat Keputusan Gubernur Nomor 34 Tahun 2017 tanggal 14 Juli 2017 tentang Gugus Tugas Pencegahan Orang Provinsi Jawa Tengah yang beranggotakan 39 orang, dari unsur OPD terkait, APH, Organisasi Profesi, Organisasi Keagamaan, Akademisi.

Di setiap provinsi dan kabupaten/kota, peran P2TP2A juga berbedabeda. Tidak semua P2TP2A memiliki peran untuk urusan tindak pidana perdagangan orang. PPT Provinsi Jawa Timur memiliki tiga fungsi, yaitu; memberikan layanan medis guna pemulihan trauma fisik maupun psikis perempuan dan anak korban kekerasan; memberikan layanan psikososial terhadap korban yang memerlukan konselor ataupun mediator dalam penanganan kasus; dan memberikan layanan hukum terhadap korban yang memerlukan konselor hukum pada kasus kekerasan. PPT Jawa Timur dalam menjalankan tugasnya melayani perempuan dan anak korban kekerasan dalam rumah tangga (KDRT) meliputi kekerasan fisik, psikis, seksual, dan penelantaran ekonomi. Selain itu, PPT Jawa Timur juga melayani korban 
kekerasan di masyarakat yang berbasis gender, meliputi kekerasan fisik, psikis, seksual, dan buman trafficking.

Terkait dengan layanan yang diberikan oleh PPT Jawa Timur dalam konteks perannya untuk menangani kasus tindak pidana perdagagan orang, dapat dilihat pada kutipan wawancara dengan Staf PPT Jawa Timur berikut ini:

"Kalau kita (PPT Jawa Timur), model layanannya satu atap. Semua itu terkordinasi di sini. Ketika korban datang, di sini bisa dilakukan penyelidikan, layanan kesehatan, pelayanan bukum, dan penanganannya. Babkan BAP dilakukan di sini."

Berdasarkan kutipan wawancara di atas, dapat diketahui bahwa PPT Jawa Timur menerapkan model layanan satu atap. Ketika korban datang, maka akan dilayani mulai dari penyelidikan, layanan kesehatan termasuk disediakan psikiater, pelayanan hukum, dan kemudian penanganannya. Hal tersebut sesuai dengan misi PPT Jawa Timur sendiri yang mana memberikan perlindungan dan rasa aman dengan pendekatan berwawasan gender bagi perempuan dan anak korban kekerasan, dengan memperhatikan hak-hak korban, dengan layanan berupa: layanan medis dan medikolegal, layanan psikososial (konseling dan psikoterapi), layanan pendampingan hukum, penyediaan rumah aman (shelter), dan pelatihan kemandirian.

Sedangkan P2TP2A Provinsi Jawa Tengah menangani isu pendidikan dan pelatihan, kewirausahaan dan pemberdayaan ekonomi keluarga, kesehatan, hukum, serta pendampingan (advokasi). Terkait peran tugas P2TP2A Provinsi Jawa Tengah dalam mencegah dan mengurangi terjadinya Tindak Pidana Perdagangan Orang (TPPO) (Human Trafficking), dapat dilihat pada kutipan wawancara dengan Staf P2TP2A Provinsi Jawa Tengah berikut ini:

"Untuk pencegahan dan mengurangi terjadinya Tindak Pidana Perdagangan Orang merupakan tupoksi dari Seksi Perlindungan Perempuan DP3AKB Provinsi Jawa Tengah, sedangkan UPTD tupoksinya adalah penanganan kasus".

Pada wawancara tersebut, dapat diketahui bahwa peran PPT Jawa Tengah adalah pada tahap pelayanan, sedangkan pencegahan menjadi tupoksi dari Seksi Perlindungan Perempuan DP3AKB (Dinas Pemberdayaan Perempuan, Perlindungan Anak, Pengendalian Penduduk dan Keluarga Berencana) Provinsi Jawa Tengah. 
Jika PPT Jawa Timur dan UPTD (Unit Pelaksana Teknis Daerah) PPT Provinsi Jawa Tengah, terkait tindak pidana perdagangan orang, berperan mulai dari penyelidikan, rehabilitasi, dan penanganan, maka lain halnya dengan P2TP2A Daerah Istimewah Yogyakarta yang tidak berperan dalam menerima korban TPPO. P2TP2A DIY hanya fokus pada masalah kekerasan terhadap anak dan perempuan. Untuk diketahui bahwa kekerasan belum tentu merupakan TPPO, tetapi sebaliknya TPPO sudah pasti ada kekerasan. Ruang lingkup kegiatan yang dilakukan oleh P2TP2A DIY adalah mensosialisasikan berbagai informasi dan peraturan yang berguna bagi peningkatan pemahaman, solidaritas, dan kemampuan terjadinya kekerasan terhadap perempuan dan anak; pelayanan pos pengaduan, konsultasi, dan pendampingan, bagi korban kekerasan perempuan dan anak selama 24 jam; konseling bidang medis, psikologis, hukum, sosial, dan kerukunan rumah tangga; rujukan; dan semi shelter, shelter, dan pascashelter. Seorang staf P2TP2A DIY, ketika berbincang dengan peneliti mengatakan bahwa memang di P2TP2A tidak menangani kasus TPPO. Fokusnya adalah pada kasus kekerasan terhadap anak dan perempuan, termasuk KDRT. Kutipannya dapat dilihat berikut ini:

" P2TP2A DIY tidak menangani TPPO. Perannya adalab untuk mencegab dan menangani tindak kekerasan terhadap perempuan dan anak."

Kemudian peneliti mengajukan pertanyaan balik, mengapa di DIY tidak ada kasus TPPO? Staf tersebut menjawab sebagai berikut:

"Di DIY memang tidak ada kasus TPPO. Kami juga tidak pernah menerima laporan."

Berdasarkan jawaban tersebut, peneliti sebenarnya dapat mengambil kesimpulan bahwa di DIY sebenarnya bukan tidak ada kasus TPPO sama sekali. Masalahnya adalah masyarakat enggan untuk melapor. Maka dari itu, jawaban staf P2TP2A DIY dapat dimengerti bahwa ketika tidak ada laporan yang masuk, itu artinya dianggap tidak ada kasus TPPO. Tidak ada laporan sama dengan tidak ada kasus tindak pidana perdagangan orang di Daerah Istimewah Yogyakarta. Oleh karena itu, kaitannya dengan ini, semua pihak yang berwenang harus intens lagi untuk mengumpulkan informasi. 
P2TP2A Provinsi Jawa Barat yang diketuai oleh istri Gubernur Jawa Barat juga berperan untuk pencegahan, menerima pengaduan penanganan sementara yang kemudian diserahkan ke pihak yang berwajib, mengadvokasi, rehabilitasi, dan reintegrasi (pemulangan). Hal tersebut dapat dilihat pada kutipan wawancara dengan salah seorang Staf P2TP2A Jawa Barat, berikut ini:

"Peran P2TP2A Jawa Barat adalah mulai dari tahap pencegahan melalui sosialisasi dan bekerja sama dengan teman-teman (P2TP2A) kabupaten/kota; menerima pengaduan rehabilitasi, penanganan sementara yang kemudian diserabkan ke pihak berwajib; mengadvokasi dengan kepolisian, dinas kesehatan, dinas sosial, dinas tenaga kerja; dan reintegrasi (pemulangan) ke daerah asal."

\section{Kendala-Kendala yang Dihadapi P2TP2A dan Stakeholder Dalam Upaya Pencegahan dan Penanganan Tindak Pidana Perdagangan Orang (Human Trafficking) di Indonesia}

Stakeholder yang dimaksud dalam penelitian ini adalah semua instansi pemerintah yang memiliki kewenangan untuk melakukan pencegahan dan penanganan tindak pidana perdagangan orang (TPPO). Faktanya adalah, meskipun di satu sisi ada upaya untuk melakukan pencegahan sampai pada tahap penanganan, sebagian besar kasus TPPO dapat dikatakan tidak bisa rampung, atau rampung tetapi bukan berarti menyelesaikan masalah, karena ada beberapa kendala yang dihadapi. Ada beberapa masalah yang dihadapi oleh P2TP2A dan juga stakebolder dalam menjalankan tugasnya, antara lain sebagai berikut:

a. Pendanaan

Masalah pendanaan di sini adalah sudah tentu jumlah dana yang dialokasikan untuk PPT/P2TP2A harus diakui tidak bisa mengcover sejumlah program yang disusun dalam jangka waktu setahun. Apalagi peran PPT/P2TP2A sangat banyak yang dimulai dari pencegahan sampai penanganan. Meskipun demikian, PPT/P2TP2A memiliki kemampuan manajerial untuk menyikapi jumlah dana yang tidak besar itu. P2TP2A Jawa Barat tetap bisa mengcover kebutuhan walaupun dana tidak besar dengan melaksanakan program-program prioritas, sedangkan PPT Jawa Timur mensiasati jumlah dana yang kecil ini dengan cara berkoordinasi 
dengan stakeholder lainnya untuk berbagi beban, sehingga pada akhirnya masalah tersebut dapat diselesaikan.

Misalnya, di kabupaten/kota, tidak semua dinas sosial memiliki dana untuk penjemputan dan pemulangan ke daerah asal. Hal ini yang menyebabkan penanganan kasus menemui kendala. Saran yang bisa dilakukan untuk menyesaikan masalah ini adalah dengan melibatkan Kementerian Dalam Negeri. Pemerintah Daerah adalah dibawah naungan Kementerian Dalam Negeri, oleh karena itu Kemendagri disarankan untuk membuat kebijakan yang secara khusus untuk kepala daerah untuk mendorong dan mendukung baik dari dari sisi teknis maupun menganggarkan dana khusus untuk penanganan TPPO yang memadai.

b. Masyarakat Enggan untuk melapor adanya masalah

Masalah kesadaran masyarakat yang enggan untuk melapor adanya masalah dihadapi oleh P2TP2A Jawa Barat. Berikut kutipannya:

"Kendala yang dihadapi adalah mereka (masyarakat) enggan untuk melaporkan kepada kita. Sudah jadi masalah yang besar, mereka baru melaporkan. Ketika masib biasa saja mereka enggan melaporkan/menyampaikan."

Peneliti dapat memamahi bahwa dalam penanganann kasus, mencegah masalah agar tidak menjadi besar tetap lebih baik daripada melakukan penanganan ketika masalah atau kasus sudah menjadi besar. Peran masyarakat dalam melakukan pencegahan baik mencegah agar tidak terjadi maupun mencegah masalah/kasus bertambah besar adalah sangat dibutuhkan perannnya dalam membantu P2TP2A dalam menjalankan tugas.

c. Proses penyesuaian kelembagaan yang baru

Proses penyesuaian kelembangaan yang baru dihadapi oleh PPT Jawa Tengah yang pada Tahun 2017 ini telah berubah menjadi UPTD kelas B. Proses penyesuain antar personil maupun lembaga membutuhkan waktu yang cukup lama, sehingga berimbas pada pelaksanaan tugas pokok dan fungsi lembaga dalam mencegah dan menangani kasus tindak pidana perdagangan orang (buman trafficking).

d. Tidak semua instansi pemerintah yang menangani TPPO mehamami prosedur 
Salah satu kelemahan penanganan kasus TPPO di Indonesia adalah tidak semua instansi pemerintah yang menangani TPPO memahani prosedur penanganan yang benar. Misalnya: ada sebagian orang yang menganggap bahwa ketika korban sudah dipulangkan ke daerah asal, maka itu dianggap sudah menyelamatkan. Padahal sebenarnya tidak demikian. Reintegrasi tersebut tidak akan memberikan kontribusi yang banyak baik bagi pencegahan dan penanganan kasus TPPO selanjutnya, jika tidak dilaporkan ke kepolisian untuk diusut sampai sedalam-dalamnya. Di sini terdapat kesalah-pahaman di dalam instansi pemeritah.

e. Belum jelasnya kebijakan restitusi

Yang dimaksud dengan "restitusi" adalah pembayaran ganti kerugian yang dibebankan kepada pelaku berdasarkan putusan pengadilan yang berkekuatan hukum tetap atas kerugian materiil dan/atau imateriil yang diderita korban atau ahli warisnya berdasarkan Undang-undang Nomor 35 Tahun 2014 tentang Tindak Pidana Pemberantasan Orang. Memang sudah ada aturan yang mengatur tentang restitusi bagi korban TPPO, tetapi itu hanya mengatur kerugian yang bersifat materiil. Lantas, bagaimana dengan kerugian immateriil, seperti kerugian harga diri, trauma, depresi, dan lain-lain? Sampai hari ini pemerintah belum bisa merumuskan aturan untuk menghitung kerugian immateriil. Masalah ini secara tidak langsung dapat menguntungkan trafficker (pelaku tindak pidana) yang hanya dibebankan untuk membayar ganti rugi kerugian materiil. Ini dapat menjadi sebuah celah dalam upaya pencegahan dan penanganan TPPO di Indonesia.

f. Belum adanya SOP pelayanan korban sehingga pelayanannya berjalan sendiri-sendiri

Belum adanya SOP yang secara spesifik mengatur tentang pelayanan terhadap korban menyebabkan setiap stakeholder seolah-seolah berjalan sendiri-sendiri dan tidak memiliki pedoman dalam penanganan kasus TPPO. Akibat lain adalah ketika setiap stakeholder masing-masing berjalan sendiri, maka penanganan kasus tidak bisa selesai karena setiap pihak melakukan penanganan sesuai dengan penafsirannya masing-masing. 
g. Tumpang-tindih tupoksi

Secara spesifik beberapa orang menyoroti peran P2TP2A yang mengambil alih peran stakebolder lainnya. Bagi sebagian orang, P2TP2A hanya berperan sebagai rumah singgah, menerima pengaduan, dan melakukan pencegahan (misalnya dalam bentuk sosialisasi). Di tingkat pusat, pada saat rehabilitasi, adalah tugas Kemensos, pemulangan dari luar negeri menjadi tugas Kemenlu. Untuk masalah kesehatan menjadi tugas Kemenkes, dan sebenarnya itu berlaku sampai ke tingkat provinsi dan kabupaten/kota. Seharusnya, P2TP2A berperan untuk melakukan tindakan pencegahan, menerima pengaduan sementara; Dinas Sosial melakukan rehabilitasi; Dinas Kesehatan melakukan tindakan psikoterapi; Dinas Tenaga Kerja memastikan bahwa korban mendapatkan pekerjaan untuk menjalani kehidupannya; dan pihak kepolisian berperan melakukan penanganan kasus dan proses hukumnya. Sebenarnya juga di setiap provinsi telah dibentuk gugus tugas penanganan TPPO, tetapi tetap saja ada tumpang tindik tupoksi.

h. Tidak semua orang bekerja dengan empati

Penanganan kasus TPPO adalah bagaimana membantu korban agar bisa terlepas dari jeratan masalah yang dihadapinya. Maka dari itu, hal tersebut berhubungan dengan tindakan kemanusiaan yang tulus. Pada kenyataannya, tidak semua orang mau bekerja denga hati dan kemanusiaan.

\section{E. Penutup}

Peran P2TP2A dalam kaitannya dengan penanganan tindak pidana perdagangan orang (TPPO), adalah sebagai berikut: pencegahan, menerima pengaduan, penyelidikan, rehabilitasi, penanganan, reintegrasi (pemulangan), pelatihan kemandirian.

Masalah dan kendala yang dihadapi oleh P2TP2A, antara lain sebagai berikut: pendanaan, masyarakat enggan untuk melapor adanya masalah, proses penyesuaian kelembagaan yang baru, tidak semua instansi pemerintah yang menangani TPPO mehamami prosedur, belum jelasnya kebijakan restitusi, belum adanya SOP pelayanan korban sehingga pelayanannya berjalan sendiri-sendiri, 
adanya tumpang-tindih tupoksi antar-stakeholder, dan tidak semua orang bekerja dengan empati.

Saran yang dapat dilakukan untuk memperkuat peran P2TP2A, antara lain: Pemerintah membut kebijakan yang lebih akomodatif dan suportif terhadap instansi-instansi yang menangani TPPO, pemerintah menyusun SOP penanganan kasus korban TPPO yang mudah dipahami oleh semua instansi yang menangani TPPO dan tidak menimbulkan mutitafsir, masyarakat berperan aktif dalam membantu pemerintah dalam melakukan tindakan pencegahan dan tidak enggan melapor jika menemui kasus TPPO; dan pemerintah segera merumuskan peraturan yang mengatur restitusi yang akomodatif baik terhadap kerugian materiill maupun immateriil.

\section{DAFTAR PUSTAKA}

Everd Scor Rider Daniel, dkk., “ Human Trafficking di Nusa Tenggara Timur”, Social Work Jurnal Vol.7 No.1 Halaman 1-129

Hakrisnowo, Hakristuti, 2003, Indonesia Court Report: Human Trafficking, Jakarta: UI

Ibrahim, Imam, A, 2013, Tinjauan Viktimologis Terhadap Kejatahan Perdagangan Orang (Human Trafficking) Di Kota Bandung. Makassar: Universitas Hasanuddin

Kedutaan Besar dan Konsulat AS di Indonesia, 2019, Laporan Tahunan Perdagangan Orang 2019

Rafikah, R., 2017. Peranan pusat pelayanan terpadu pemberdayaan perempuan dan anak (P2TP2A) dalam menghapuskan kekerasan dalam rumah tangga (KDRT) di kota Bukittinggi. Islam Realitas: Journal of Islamic \& Social Studies, 1(2), 173- 186.

Sugiyono, 2010, Metode Penelitian Pendidikan, Pendekatan Kualitatif, dan R\&D, Bandung: Alfabeta

Supardjaja, Komariah, E.,2002, Ajaran Sifat Melawan Hukum Materil dalam Hukum Pidana, Studi Kasus tentang Penerapan dan Perkembangannya dalam Yurisprudensi, Bandung: Alumni

United Nations Office on Drug and Crime (UNODC), 2012, World Drug Report. United Nations publication, Sales No. E.12.XI.1

Utami, P. N, 2016, Optimalisasi Pemenuban Hak Korban Kekerasan terhadap Perempuan melaluui Pusat terpadu, Jurnal HAM 7(1).

Undang-undang Nomor 21 Tahun 2007 tentang pemberantasan Tindak Pidana Perdagangan Orang

Undang-undang Nomor 35 Tahun 2014 tentang Perubahan Undang-Undang Nomor 21 Tahun 2007 tentang pemberantasan Tindak Pidana Perdagangan Orang

Peraturan Menteri Pemberdayaan Perempuan dan Perlindungan Anak Nomor 6 tahun 2015 tentang Sistem Pemberdayaan Perempuan dan Perlindungan Anak

Undang-undang Nomor 23 tahun 2002 tentang Perlindungan Anak 
SK Gubernur Jawa Timur No.188/128/kpts/013/2017 Tentang Tim Pengelola PPT RS. Bhayangkara Korban Trafiking dan KDRT.

Keputusan Gubernur Daerah Istimewah Yogyakarta No.132/KEP/2005

Peraturan Gubernur Jawa Tengah Nomor 95 Tahun 2016 tentang Organisasi Dan Tata Kerja Unit Pelaksana Teknis Dinas Pemberdayaan Perempuan, Perlindungan Anak, Pengendalian Penduduk dan Keluarga Berencana Provinsi Jawa Tengah 